Annals of Warsaw University of Life Sciences - SGGW

Land Reclamation No 47 (1), 2015: 31-42

(Ann. Warsaw Univ. Life Sci. - SGGW, Land Reclam. 47 (1), 2015)

\title{
Removal of dissolved metals by activated carbon from road runoff in batch systems - equilibrium and kinetic*
}

\author{
KATARZYNA PAWLUK, JOANNA FRONCZYK \\ Department of Geotechnical Engineering, Warsaw University of Life Sciences - SGGW
}

\begin{abstract}
Removal of dissolved metals by activated carbon from road runoff in batch systems - equilibrium and kinetic. Activated carbon is an effective sorbent for removing organic and inorganic contaminants from aqueous solutions. In conducted experiments, granulated activated carbon (GAC) was used to examine the adsorption processes of heavy metals $(\mathrm{Cd}, \mathrm{Cu}, \mathrm{Ni}, \mathrm{Pb}$ and $\mathrm{Zn}$ ). Studies (performed in batch system) were carried out as a function of time, heavy metals concentration and $\mathrm{pH}$ values. The obtained results show that GAC effectively removes mentioned metals. Numerous kinetic models were used to investigate the mechanism of adsorption processes. Using the Langmuir isotherm, the maximum adsorption capacities were calculated to be 3.010 , $3.662,4.430,3.800$ and $4.169 \mathrm{mg} \cdot \mathrm{g}^{-1}$ for $\mathrm{Cd}, \mathrm{Cu}$, $\mathrm{Ni}, \mathrm{Pb}$ and $\mathrm{Zn}$, respectively, in neutral conditions and $2.684,2.578,3.482,2.592$ and $2.253 \mathrm{mg} \cdot \mathrm{g}^{-1}$ in acidic conditions.
\end{abstract}

Key words: activated carbon, heavy metals, road runoff, adsorption

\section{INTRODUCTION}

One of the significant sources of contamination are road infrastructure and transport. During rainfall, a wide range of substances, including heavy metals, polycycling aromatic hydrocarbons (PAHs), de-icing agents, oil, grease and sediments are washed from roads into surface and groundwater (Béchet et al. 2010, Fach and Dierkes 2011). A wide range of metals have been detected in runoff of those the most commonly reported are $\mathrm{Cd}, \mathrm{Cu}, \mathrm{Ni}, \mathrm{Pb}$ and $\mathrm{Zn}$ (Blecken et al. 2012). Acid precipitation (acid rain) are strictly dependent on transport pollution such contaminants as oxides of nitrogen $\left(\mathrm{NO}_{\mathrm{x}}\right)$ and sulphite $\left(\mathrm{SO}_{2}\right)$. Acid rain (having a $\mathrm{pH}$ level of less than 5.6) is caused by nitric and sulphur acids formed by mixing of $\mathrm{NO}_{\mathrm{x}}$ and $\mathrm{SO}_{2}$ with moisture/vapour in the atmosphere. The $\mathrm{NO}_{x}$ and $\mathrm{SO}_{2}$ gases are produced during a variety of industrial, mine processes (e.g. fossil fuels) and transport. Soil by buffering capacity may have neutralized some of the acidity of the acid rainwater. On the other hand, the environmental degradation may cause rapid decrease of soil $\mathrm{pH}$ and in consequence accelerate soil weathering and remove nutrients (GAO 13-39 2013). Moreover, in more acidic environment some toxic elements, for example heavy metals, become more soluble and might migrate for long distance from the source. These phenomena

\footnotetext{
* This research was supported by Grant N N523 561638 from National Science Centre, Poland and the European Union funds by the European Social Fund.
} 
depends on metal bonding forces of the soil particles and on dissolving action of hydrogen ions, which can break down rocks and soil particles. Heavy metals are the contaminants of grates anxiety, because they are non-biodegradable and toxic for environment. Therefore, remediation of these pollutants is a great challenge. To protect the environment in the vicinity of roads different systems might be implemented such as collection basins, wetland systems, oil separators and bioremediation techniques (Gotvajn and Zagorc-Končan 2009, Kluge and Wessolek 2012). Several research studies have found significant levels of heavy metals, such as $\mathrm{Cd}, \mathrm{Cu}, \mathrm{Ni}, \mathrm{Pb}$, and $\mathrm{Zn}$ in urban stormwater, which the median values of concentrations were as follows (in $\mathrm{mg} \cdot \mathrm{L}^{-1}$ ): $0.009-0.100$ for $\mathrm{Cd}$, 0.006-0.100 for $\mathrm{Cu}, 0.008-0.020$ for $\mathrm{Ni}, 0.008-1.900$ for $\mathrm{Pb}, 0.06-19.100$ for Zn (Davis et al. 1999, Davis and Birch 2001, Kayhanian et al. 2003, Barrett et al. 2006, Kayhanian et al. 2007; Barrett 2008, Lau et al. 2009). However, in this case the typical water purification methods (e.g. chemical precipitation, reduction, adsorption, osmosis etc.) could be implemented. In general, those methods are very expensive and energy-intensive, as well as demand large quantities of chemical reagents. Among these, adsorption onto granular activated carbon (GAC) in treatment zone of permeable reactive barrier seems to be a potential alternative and may become an efficient and relatively low-cost technology. GAC is widely used for dechlorination, industrial wastewater conditioning (Zayat and Smith 2010) and groundwater re- mediation - permeable reactive barriers (Roehl et al. 2006). A number of studies confirm that activated carbon might be wildly used for heavy metals removal, i.a., Sulaymon et al. (2012), Liu et al. (2013) and Venkatesan et al. (2013). The aim of these studies was to evaluate the application possibility of GAC granular activated carbon as a reactive media for road runoff purification. Sorption test, including batch equilibrium and kinetic tests, were carried out using multicomponent heavy metals solution. Experimental data based on measurements of chemical analyses of solutions after tests have been fitted to different models - two kinetic and three isotherm models previously reported in literature.

\section{MATERIAL AND METHODS}

\section{Adsorbent and adsorbates}

Granular activated carbon (GAC) used in the tests was obtained from Active Carbon Research and Production Company, Mrozy, Poland. Its particle size, specific gravity and bulk density were $0.40-1.00$, 1.96 and $0.45 \mathrm{~mm}$, respectively. Moreover, surface area and porosity analyzer (ASAP 2020M Micromeritics, USA), scanning electron microscope (SEM) images (FEG Quanta 250, USA) and X-ray diffraction (Philips X'Pert APD, the Netherlands) spectra were used to detailed characterization of GAC particles.

All tests were performed using a dilute solutions simulated the road runoff. The solutions were prepared by mixing $5 \mathrm{~mL}$ of distilled water and required quantity of analytical reagent grade of 
cadmium, copper, nickel, lead and zinc $(6.7 \mathrm{~mL}$ for kinetic tests and $0.1,0.2$, $0.5,1.0,1.5,2.0,2.5,4.0,5.5,7.0,8.5$, $10.0 \mathrm{~mL}$ for equilibrium tests) and then diluted to $100 \mathrm{~mL}$ with distilled water. The concentrations used in presented investigations were higher than a maximal allowable concentration (MAC) for groundwater in Poland (Polish Journal of Laws from 2006, No 137, item 984 as amended).

\section{Batch sorption test}

The kinetic and equilibrium tests were carried out using $2 \mathrm{~g}$ of GAC and $100 \mathrm{~mL}$ of aqueous solutions. Batch kinetic experiments for $67 \mathrm{mg} \cdot \mathrm{L}^{-1}$ mixed metal solution were conducted to evaluate the uptake rates and contact times needed to achieve equilibrium. To determine the time in which the adsorption equilibrium under static conditions occurs, a set of sorption measurements of metal concentration in the multicomponent solution were undertaken after $1,3,6,10,24$ and $48 \mathrm{~h}$. In equilibrium tests the initial concentrations of metals were vasried from 0 to $100 \mathrm{mg} \cdot \mathrm{L}^{-1}$ and the contact time was $48 \mathrm{~h}$. Aqueous solution without adsorbates were used as control samples. The double-blind tests and the other aqueous solutions containing mixtures of $\mathrm{Cd}, \mathrm{Cu}, \mathrm{Ni}, \mathrm{Pb}, \mathrm{Zn}$ and reactive material were placed into 250 $\mathrm{mL}$ bottle made of polyethylene. Before tests, the values of $\mathrm{pH}$, temperature and electrical conductivity were measured using a portable instrument $\mathrm{pH} / \mathrm{con}$ ductivity meter (SCHOTT, Germany). The samples were then placed into rotary shaker (GFL, Germany) set at 15 rpm for time required for different type of batch tests, after which $\mathrm{pH}$, temperature and conductivity values were measured. The tests were performed in duplex at laboratory temperature of $20-22^{\circ} \mathrm{C}$. Before chemical analyses the solution was centrifuged at $3,000 \mathrm{rpm}$ for $5 \mathrm{~min}$. The final concentrations of the heavy metal ions in the solution were measured by plasma - atomic absorption spectroscopy ICP-AAS (Thermo Scientific, USA). The unit adsorption amount and the removal ratio of heavy metals $\mathrm{R}(\%)$ were calculated by (Michel and Kiedryńska 2011):

$$
q_{t}=\frac{\left(C_{0}-C_{e}\right) \cdot V}{m}
$$

and

$$
R(\%)=\frac{C_{0}-C_{t}}{C_{0}} \cdot 100 \%
$$

where:

$q_{t} \quad-$ unit adsorption amount (mg.g $\mathrm{g}^{-1}$,

$C_{0}, C_{e}, C_{t}-$ initial, equilibrium and final concentrations of heavy metal ions, respectively $\left(\mathrm{mg} \cdot \mathrm{L}^{-1}\right)$,

$V \quad-$ volume of the aqueous solution $(\mathrm{L})$,

$m \quad-$ mass of adsorbent (mg).

For kinetic tests data interpretation the following models were used: pseudo-first and pseudo-second order kinetics models and intraparticle diffusion model. Formulas of the applied models are presented in Table 1.

Equilibrium tests results were analyzed using Langmuir, Redlich-Peterson and Temkin isotherm models. The equations of the applied isotherm models are presented in Table 2. 
TABLE 1. The kinetic models

\begin{tabular}{|l|c|c|}
\hline Model & Equation & Plot \\
\hline $\begin{array}{l}\text { Pseudo-first order } \\
\text { (Ho and McKay 1999, } \\
\text { Ho 2006) }\end{array}$ & $\log \left(q_{e}-q_{t}\right)=\log \left(q_{e}\right)-\frac{k_{p 1} t}{2.203}$ & $\log \left(q_{e}-q_{t}\right)$ vs. $t$ \\
\hline $\begin{array}{l}\text { Pseudo-second order } \\
\text { Ho 2006, Ibrahim et al. } \\
\text { 2013) }\end{array}$ & $\frac{t}{q_{t}}=\frac{1}{k_{\mathrm{p} 2} q_{e}^{2}}+\frac{t}{q_{e}}$ & $\frac{t}{q_{t}}$ vs. $t$ \\
\hline $\begin{array}{l}\text { Intraparticle diffusion } \\
\text { (Alkan et al. 2007) }\end{array}$ & $q_{t}=k_{\text {int }} \cdot t^{1 / 2}$ & $q_{t}$ vs. $t^{1 / 2}$ \\
\hline
\end{tabular}

Where: $q_{e}$ is the equilibrium adsorption capacity of the copper ions $\left(\mathrm{mg} \cdot \mathrm{g}^{-1}\right) ; q_{t}$ is the adsorption capacity determined after time $t\left(\mathrm{mg} \cdot \mathrm{g}^{-1}\right) ; k_{p 1}$ and $k_{p 2}$ are the equilibrium rate constants of the pseudo-first order model $\left(\mathrm{min}^{-1}\right)$ and pseudo-second order model $\left(\mathrm{g} \cdot \mathrm{mg}^{-1} \cdot \mathrm{min}^{-1}\right)$, respectively; $k_{\text {int }}$ is the intraparticle diffusion rate constant $\left(\mathrm{mg} \cdot \mathrm{g}^{-1} \cdot \mathrm{min}^{-1 / 2}\right)$.

TABLE 2. The isotherm models

\begin{tabular}{|l|c|c|}
\hline Isotherm & Non-linear form & Linear form \\
\hline $\begin{array}{l}\text { Langmuir } \\
\text { (Langmuir 1916) }\end{array}$ & $q_{e}=\frac{q_{\max } \cdot K_{L} \cdot C_{e}}{1+K_{L} \cdot C_{e}}$ & $\frac{C_{e}}{q_{e}}=\frac{C_{e}}{q_{\max }}+\frac{1}{K_{L} \cdot q_{\max }}$ \\
\hline $\begin{array}{l}\text { Temkin } \\
\text { Temkin and Pyzhev } \\
1940)\end{array}$ & $q_{e}=B \cdot \ln \left(A \cdot C_{E}\right)$ & $q_{e}=B \cdot \ln A+B \cdot \ln C_{e}$ \\
\hline $\begin{array}{l}\text { Redlich-Peterson } \\
\text { Redlich and Peterson } \\
\text { 1959, Jossens et al. 1978) }\end{array}$ & $q_{e}=\frac{K_{R} \cdot C_{e}}{1+b_{R} \cdot C_{e}^{\beta}}$ & $\ln \left(K_{R} \cdot \frac{C_{e}}{q_{e}}-1\right)=g \ln \left(C_{e}\right)+\ln \left(b_{R}\right)$ \\
\hline
\end{tabular}

Where: $q_{e}$ is the adsorption capacity $\left(\mathrm{mg} \cdot \mathrm{g}^{-1}\right) ; K_{L}$ is the Langmuir adsorption constant related to the affinity of the binding sites $\left(\mathrm{L} \cdot \mathrm{mg}^{-1}\right) ; q_{\max }$ is the maximum amount of heavy metal ions per unit mass of adsorbent when all bindings sites are occupied $\left(\mathrm{mg}^{-1} \mathrm{~g}^{-1}\right) ; C_{e}$ is equilibrium concentration of heavy metals $\left(\mathrm{mg} \cdot \mathrm{L}^{-1}\right) ; A$ is the Temkin isotherm equilibrium binding constant $\left(\mathrm{L} \cdot \mathrm{mg}^{-1}\right) ; B$ is the Temkin isotherm equilibrium constant; $K_{R}\left(\mathrm{~L} \cdot \mathrm{mg}^{-1}\right), b_{R}\left(\mathrm{~L} \cdot \mathrm{mg}^{-1}\right)$ and $\beta$ are Redlich-Peterson isotherm constants.

Character of adsorption processes may be determined using a dimentionless constant commonly known as separation factor $-R_{L}$ (Hall et al. 1966):

$$
R_{L}=\frac{1}{1+K_{L} \cdot C_{0}}
$$

When $R_{L}$ is between 0 and 1 Langmuir isotherm is favourable, for $R_{L}$ above 1 adsorption nature is unfavourable, for $R_{L}$ equal to 1 adsorption has linear form and is irreversible when $R_{L}$ equals 0 .

\section{RESULTS AND DISCUSSION}

\section{Characterization of the adsorbent}

Figure 1 represents the XRD pattern and scanning electron images of GAC sample. Pattern and increased values

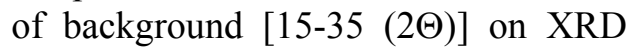
spectra of the sample shows, that the dominant mineral component is amorphous substance characteristic for activated carbons. The characteristic interplanar spacing $(4.255,3.344,2.456$, $2.283,2.237,2.128,1.981 \AA$ ) attributed 

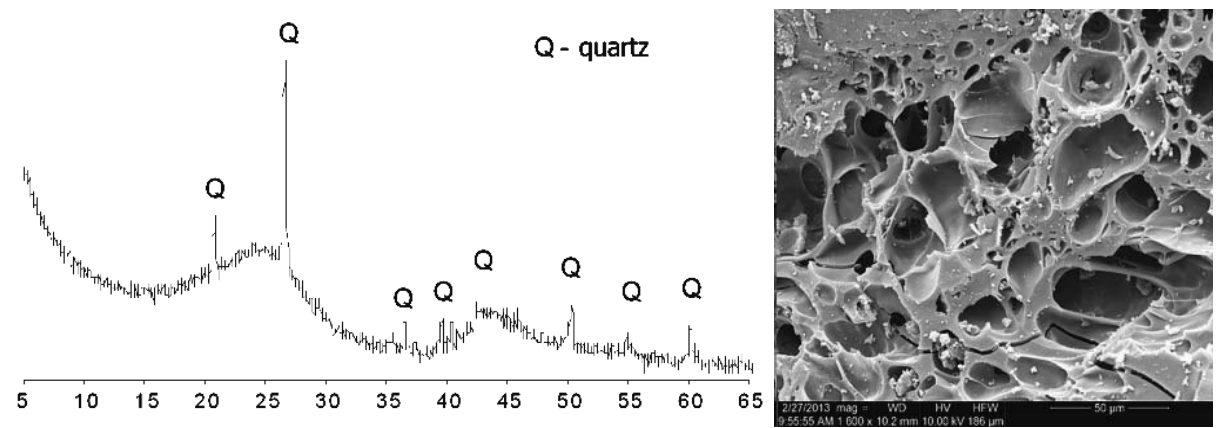

FIGURE 1. The XRD pattern and SEM images of the granular activated carbon sample

to quartz as an additional mineral component of the sample. The observations of microstructure lead to the conclusion that the surface of reactive material was highly porous and rough. The pores were circular in shape and were dissimilar in size (from 10 to $300 \mu \mathrm{m}$ ).

The reactive material is characterized by extraordinary specific surface area, which was determined at $856 \mathrm{~m}^{2} \cdot \mathrm{g}^{-1}$. The total pore volume of GAC was $0.4268 \mathrm{~mL} \cdot \mathrm{g}^{-1}$.

\section{Kinetic tests}

In kinetic test the low $\mathrm{pH}$ values of initial solutions were predicted due to less favorable conditions - the lower intensity of adsorption processes. Based on the removal ratio (Table 2), the equilibrium time required for adsorption of heavy metals on granular activated carbon was determined to be about $48 \mathrm{~h}$. The obtained data indicate that the adsorption processes were slow and evenly distributed over time. The unit adsorption amount of heavy metals $(\mathrm{Cd}, \mathrm{Cu}, \mathrm{Ni}, \mathrm{Pb}, \mathrm{Zn})$ slowly increases until it reaches maximum level after $48 \mathrm{~h}$. The final removal ratios were as follows $45.62 \%$ for $\mathrm{Cd}, 61.12 \%$ for $\mathrm{Cu}, 59.91 \%$ for $\mathrm{Ni}, 65.13 \%$ for $\mathrm{Pb}$ and $41.87 \%$ for Zn. Apparently, low reduction of previously mentioned metals was due to low $\mathrm{pH}$ values of initial solutions (Srivastava et al. 2007). Predicted parameters of sorption kinetics are shown in Table 3 and graphical interpretation of the test results are shown in Figures 2 and 3 .

TABLE 3. Effect of contact time on heavy metals removal by adsorption onto granulated activated carbon

\begin{tabular}{|c|c|c|c|c|c|}
\hline $\begin{array}{c}\text { Contact time } \\
(\mathrm{h})\end{array}$ & $\begin{array}{c}\text { Removal ratio } \\
\text { of Cd (\%) }\end{array}$ & $\begin{array}{c}\text { Removal ratio } \\
\text { of } \mathrm{Cu}(\%)\end{array}$ & $\begin{array}{c}\text { Removal ratio } \\
\text { of } \mathrm{Ni}(\%)\end{array}$ & $\begin{array}{c}\text { Removal ratio } \\
\text { of } \mathrm{Pb}(\%)\end{array}$ & $\begin{array}{c}\text { Removal ratio } \\
\text { of } \mathrm{Zn}(\%)\end{array}$ \\
\hline 1 & 8.75 & 12.49 & 19.05 & 16.19 & 5.39 \\
\hline 3 & 8.59 & 20.63 & 13.22 & 24.94 & 4.56 \\
\hline 6 & 19.07 & 32.12 & - & 32.52 & 15.14 \\
\hline 10 & 21.26 & 34.18 & 30.42 & - & 24.81 \\
\hline 24 & 28.57 & 55.78 & 41.94 & 47.27 & 21.69 \\
\hline 48 & 45.62 & 61.12 & 59.91 & 65.13 & 41.87 \\
\hline
\end{tabular}



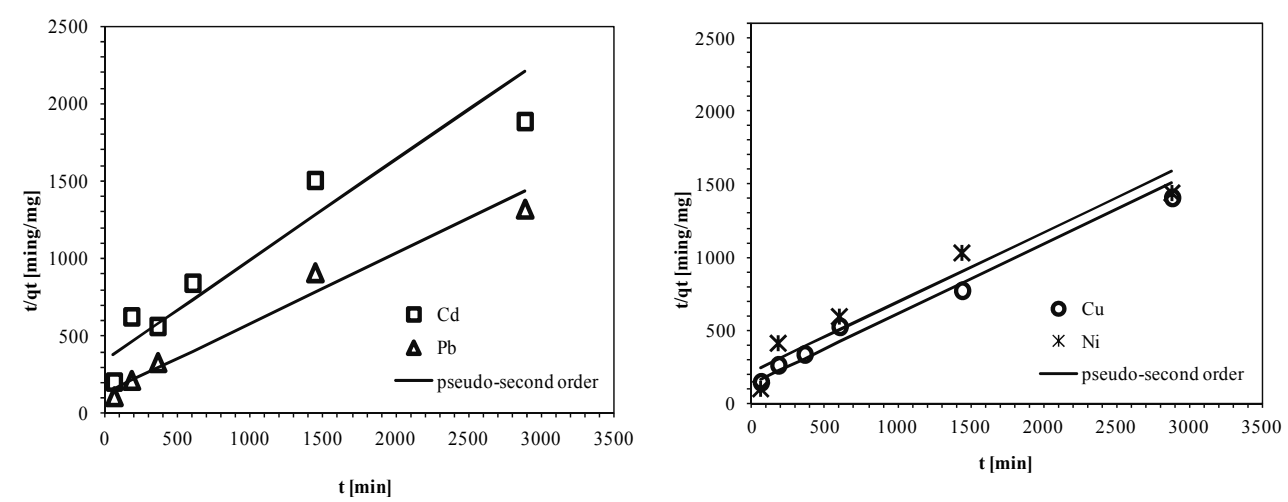

FIGURE 2. Fitting test data with the pseudo-second order kinetic model
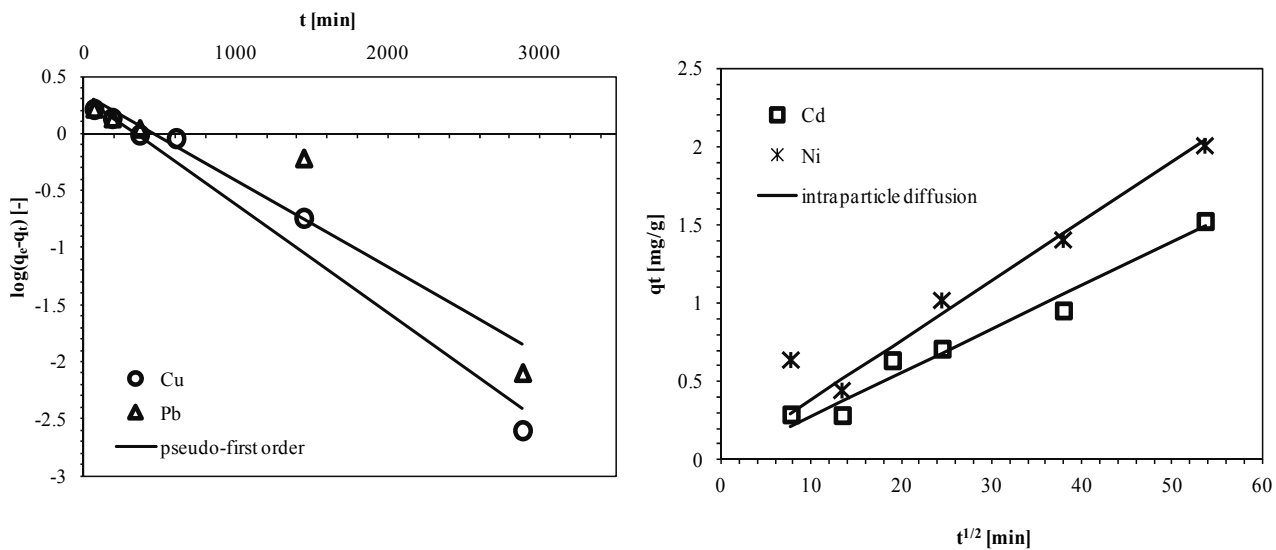

FIGURE 3. Fitting test data with the pseudo-first order kinetic model and the intraparticle diffusion model

According to the correlation coefficient $\mathrm{R}^{2}$, the obtained data were well fitted to pseudo-second order kinetic model. The coefficients of determination $\left(\mathrm{R}^{2}\right)$ for all the ions present in solution $(\mathrm{Cd}, \mathrm{Cu}, \mathrm{Ni}, \mathrm{Pb}$ and $\mathrm{Zn})$ were as follows $0.909,0.989,0.969,0.969$ and 0.721 (Table 4). The kinetics reaction of the active carbon is usually described by the pseudo-second order model, which is confirmed by several studies, including: Ho and McKay (1999), Rivas et al. (2005), Sulaymon et al. (2012). The pseudo-second order model is based on the processes of chemisorptions and the assumption that the limiting factor may be electrostatic and intermolecular forces between the adsorbent and adsorbate (Ho and McKey 1999, Ho 2006). The pseudo-second order kinetic parameters indicate that the copper, lead and nickel ions were removed from the solution in the greatest extent.

The test results for heavy metals removal were also plotted using pseudo-first order kinetic model and intraparticle diffusion model. The models gave the well fit with the experimental data for all metal ions (except lead for intraparticle diffusion model) with $\mathrm{R}^{2}$ values 
TABLE 4. The kinetic constants of heavy metals adsorption

\begin{tabular}{|l|c|c|c|c|c|}
\hline Models & $\mathrm{Cd}$ & $\mathrm{Cu}$ & $\mathrm{Ni}$ & $\mathrm{Pb}$ & $\mathrm{Zn}$ \\
\hline \multicolumn{7}{|c|}{ Pseudo-first order kinetics equation } \\
\hline$k_{1}\left(\mathrm{~min}^{-1}\right)$ & 0.002 & 0.002 & 0.003 & 0.002 & 0.001 \\
\hline$q_{e}\left(\mathrm{mg} \cdot \mathrm{g}^{-1}\right)$ & 2.499 & 2.515 & 3.515 & 2.385 & 1.633 \\
\hline $\mathrm{R}^{2}(-)$ & 0.875 & 0.976 & 0.870 & 0.905 & 0.881 \\
\hline \multicolumn{7}{|c|}{ Pseudo-second order kinetics equation } \\
\hline$k_{2}\left(\mathrm{~g} \cdot \mathrm{mg}^{-1} \cdot \mathrm{min}^{-1}\right)$ & 0.001 & 0.001 & 0.001 & 0.002 & 0.001 \\
\hline$q_{e}\left(\mathrm{mg} \cdot \mathrm{g}^{-1}\right)$ & 1.788 & 2.339 & 2.287 & 2.200 & 1.778 \\
\hline $\mathrm{R}^{2}(-)$ & 0.909 & 0.989 & 0.969 & 0.969 & 0.721 \\
\hline \multicolumn{7}{|c|}{ Intraparticle diffusion model } \\
\hline$k_{\text {int }}\left(\mathrm{mg} \cdot \mathrm{g}^{-1} \cdot \mathrm{min}^{-1 / 2}\right)$ & 0.028 & 0.044 & 0.038 & - & 0.025 \\
\hline $\mathrm{R}^{2}(-)$ & 0.965 & 0.895 & 0.915 & - & 0.877 \\
\hline
\end{tabular}

ranging from 0.989 to 0.870 . The linear plots of data were presented for metals with the highest value of $\mathrm{R}^{2}$ (Fig. 3).

\section{Equilibrium tests}

The adsorption equilibrium tests were conducted at different initial solution conditions - at $\mathrm{pH}$ of 2.0 and 6.0 . The $\mathrm{pH}$ values of model solutions influence the amount of heavy metals adsorption. It is well known that surface charge of sorbent can be affected by changing of $\mathrm{pH}$ values. For the acidic condition the adsorption processes were on the lower level. The experimental data for heavy metals were correlated with three isotherm models Langmuir, Redlich-Peterson and Temkin. The parameters as well as graphical interpretation of mentioned isotherms are shown in Table 5 and Figure 4.

The amounts of adsorption show non-linear relationship on the equilibrium concentration. Based on Table 5 and coefficient of determination, the Langmuir model gives the best fitting for tests data. The adsorption capacities were estimated to be $2.684 \mathrm{mg} \cdot \mathrm{g}^{-1}$ for cadmium, $2.578 \mathrm{mg} \cdot \mathrm{g}^{-1}$ for cooper, $3.482 \mathrm{mg} \cdot \mathrm{g}^{-1}$ for nickel, $2.592 \mathrm{mg} \cdot \mathrm{g}^{-1}$ for lead and $2.253 \mathrm{mg} \cdot \mathrm{g}^{-1}$ for zinc. The calculated $\mathrm{R}^{2}$ were $0.908,0.906,0.862$, 0.899 and 0.839 , respectively. Compared to Langmuir isotherm estimated values of $\mathrm{R}^{2}$ for Redlich-Peterson model were lower in the range of $0.484-0.720$. The graphic interpretation of the experimental data of $\mathrm{Pb}$ and $\mathrm{Zn}$ for this model was without a solution. The values of $\beta$ parameter (equal to one) indicate that Langmuir model should be more appropriate (Otun et al. 2006). Moreover, the Temkin isotherm was best fitted with $\mathrm{Ni}$ adsorption processes.

In the neutral conditions $(\mathrm{pH}=6.0)$ the processes of heavy metals adsorption were more intense (Table 6 and Fig. 5). The maximum adsorption amount for each metal were higher than in acidic conditions with the values (in $\mathrm{mg} \cdot \mathrm{g}^{-1}$ ) of 3.010, 3.662, 4.430, 3.800 and 4.169 for $\mathrm{Cd}, \mathrm{Cu}, \mathrm{Ni}, \mathrm{Pb}$ and $\mathrm{Zn}$, respectively. Based on the coefficient of determination $(0.998,0.986,0.684,0.966,0.984)$, the Langmuir model allow for the better fit of the test data. The lower adsorption 
TABLE 5. Langmuir, Redlich-Peterson and Temkin isotherm parameters $(\mathrm{pH}=2.0)$

\begin{tabular}{|l|c|c|c|c|c|}
\hline Models & $\mathrm{Cd}$ & $\mathrm{Cu}$ & $\mathrm{Ni}$ & $\mathrm{Pb}$ & $\mathrm{Zn}$ \\
\hline \multicolumn{7}{|c|}{ Langmuir } \\
\hline$q_{\max }\left(\mathrm{mg} \cdot \mathrm{g}^{-1}\right)$ & 2.684 & 2.578 & 3.482 & 2.592 & 2.253 \\
\hline$K_{L}\left(\mathrm{~L} \cdot \mathrm{mg}^{-1}\right)$ & 0.229 & 0.156 & 0.118 & 8.663 & 0.197 \\
\hline $\mathrm{R}^{2}(-)$ & 0.908 & 0.906 & 0.862 & 0.899 & 0.839 \\
\hline$R_{L}(-)$ & $0.038-0.149$ & $0.002-0.007$ & $0.071-0.253$ & $0.003-0.006$ & $0.044-0.167$ \\
\hline \multicolumn{7}{|c|}{ Redlich-Peterson } \\
\hline$K_{R}\left(\mathrm{~L} \cdot \mathrm{mg}^{-1}\right)$ & 0.414 & 0.333 & 0.529 & - & - \\
\hline$b_{R}(-)$ & 0.136 & 0.105 & 0.151 & - & - \\
\hline$\beta(-)$ & 1.000 & 1.000 & 1.000 & - & - \\
\hline $\mathrm{R}^{2}(-)$ & 0.649 & 0.720 & 0.484 & - & - \\
\hline \multicolumn{7}{|c|}{ Temkin } \\
\hline$A\left(\mathrm{~L} \cdot \mathrm{mg}^{-1}\right)$ & - & - & 1.767 & - & - \\
\hline$B\left(\mathrm{~L} \cdot \mathrm{mg}^{-1}\right)$ & - & - & 1.774 & - & - \\
\hline $\mathrm{R}^{2}(-)$ & - & - & 0.976 & - & - \\
\hline
\end{tabular}
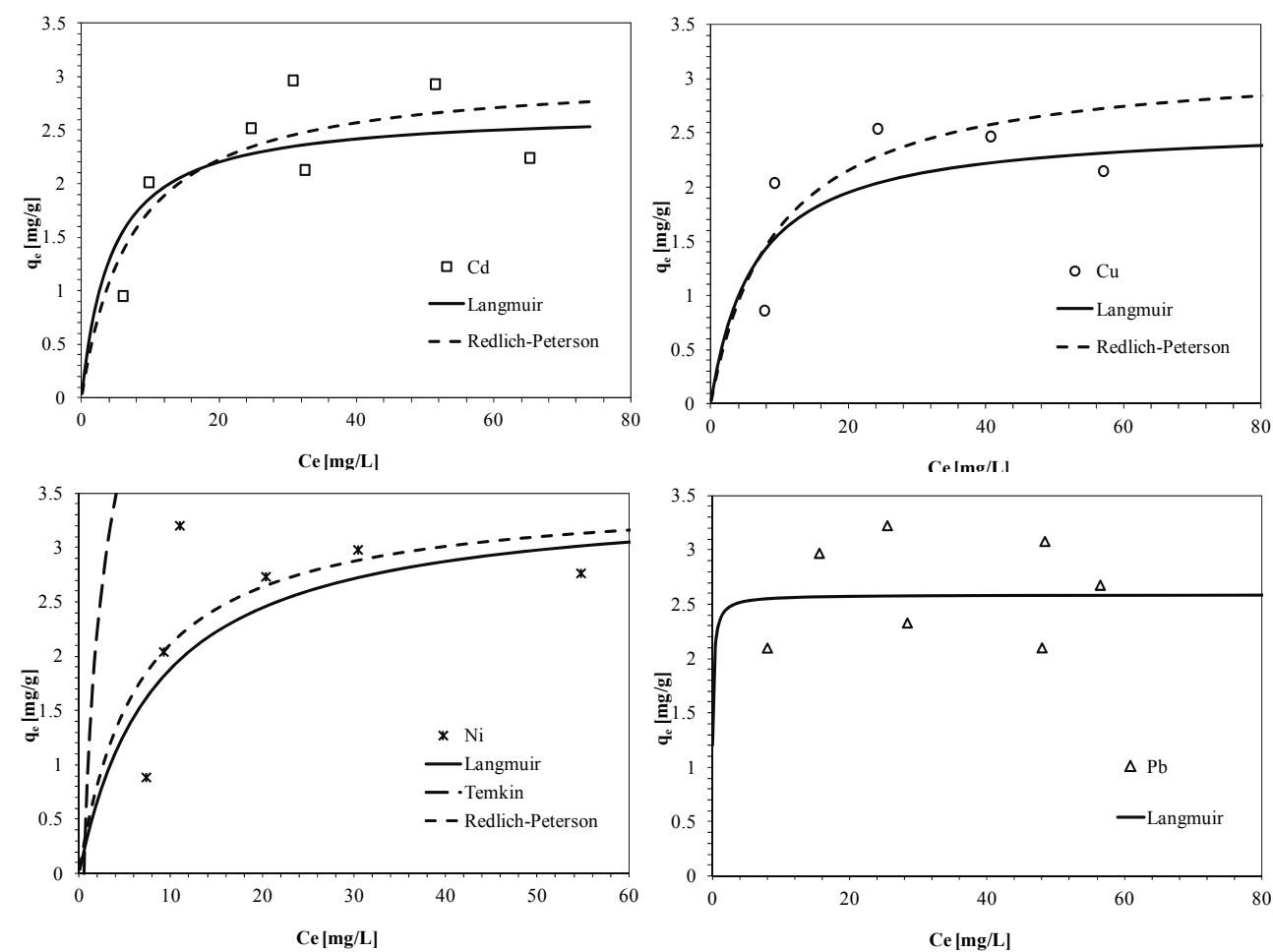

FIGURE 4. Isothermal adsorption lines for $\mathrm{Cd}, \mathrm{Cu}, \mathrm{Ni}, \mathrm{Pb}$ at acidic conditions 
FIGURE 4 (continued). Isothermal adsorption lines for $\mathrm{Zn}$ at acidic conditions

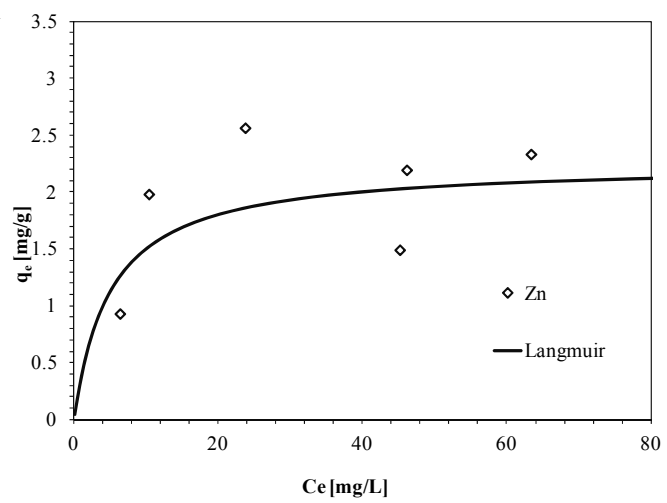

TABLE 6. Langmuir, Redlich-Peterson and Temkin isotherm parameters $(\mathrm{pH}=6.0)$

\begin{tabular}{|c|c|c|c|c|c|}
\hline Models & $\mathrm{Cd}$ & $\mathrm{Cu}$ & $\mathrm{Ni}$ & $\mathrm{Pb}$ & $\mathrm{Zn}$ \\
\hline \multicolumn{6}{|c|}{ Langmuir } \\
\hline$q_{\max }\left(\mathrm{mg} \cdot \mathrm{g}^{-1}\right)$ & 3.010 & 3.662 & 4.430 & 3.800 & 4.169 \\
\hline$K_{L}\left(\mathrm{~L} \cdot \mathrm{mg}^{-1}\right)$ & 8.284 & 6.924 & 0.533 & 7.807 & 4.618 \\
\hline $\mathrm{R}^{2}(-)$ & 0.998 & 0.986 & 0.684 & 0.966 & 0.984 \\
\hline$R_{L}(-)$ & $0.001-0.108$ & $0.002-0.126$ & $0.022-0.652$ & $0.002-0.114$ & $0.002-0.178$ \\
\hline \multicolumn{6}{|c|}{ Redlich-Peterson } \\
\hline$K_{R}\left(\mathrm{~L} \cdot \mathrm{mg}^{-1}\right)$ & 29.355 & - & 10.362 & - & - \\
\hline$b_{R}(-)$ & 12.553 & - & 5.027 & - & - \\
\hline$\beta(-)$ & 0.923 & - & 0.719 & - & - \\
\hline $\mathrm{R}^{2}(-)$ & 0.632 & - & 0.883 & - & - \\
\hline \multicolumn{6}{|c|}{ Temkin } \\
\hline$A\left(\mathrm{~L} \cdot \mathrm{mg}^{-1}\right)$ & - & - & 36.029 & - & - \\
\hline$B\left(\mathrm{~L} \cdot \mathrm{mg}^{-1}\right)$ & - & - & 0.535 & - & - \\
\hline $\mathrm{R}^{2}(-)$ & - & - & 0.813 & - & - \\
\hline
\end{tabular}

capacities in acidic conditions could be attributed to the metal ions competitions with $\mathrm{H}^{+}$for the binding sites of the reactive material (Nasir et al. 2007). Once more, the adsorption processes of $\mathrm{Ni}$ ions were described using the Temkin model, which contains a factor that directly taking into account of adsorbent - adsorbate interactions by ignoring the extremely low and large value of concen- trations. The experimental data were not modelled as well using the Redlich-Peterson equation across the concentration range studied. In summary, the heavy metals from solution in acidic and natural conditions were favorably removed by the sorption processes, what may be found in the range of the $R_{L}$ parameter value (between 0 and 1). 

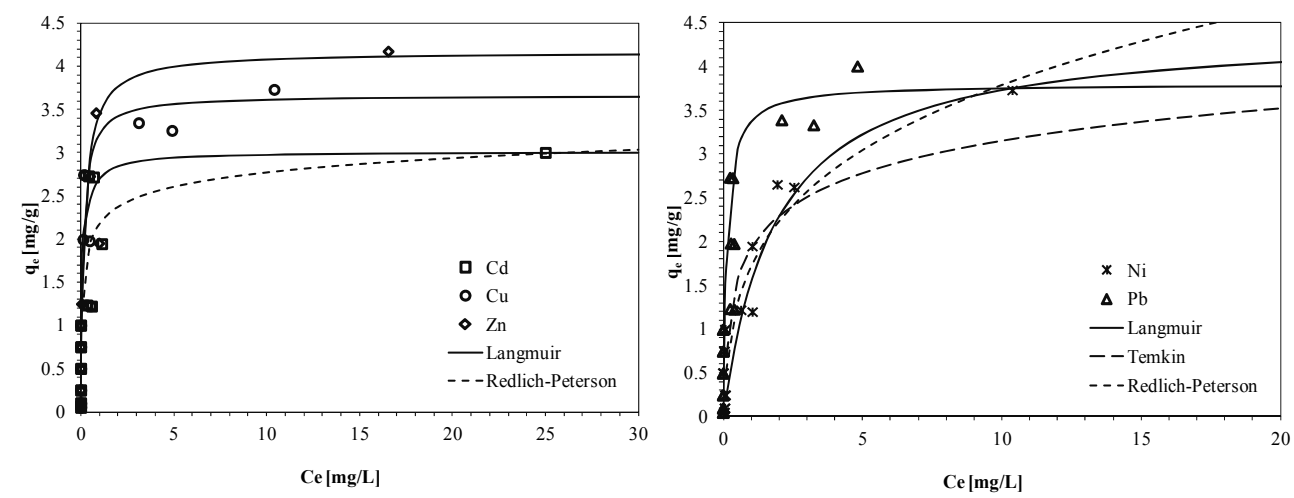

FIGURE 5. Isothermal adsorption lines for $\mathrm{Cd}, \mathrm{Cu}, \mathrm{Ni}, \mathrm{Pb}$ and $\mathrm{Zn}$ at neutral conditions

\section{CONCLUSIONS}

The study presented in this paper has demonstrated that granular activated carbon (GAC) can be used as an effective heavy metals $(\mathrm{Cd}, \mathrm{Cu}, \mathrm{Ni}, \mathrm{Pb}$ and $\mathrm{Zn)}$ adsorbant from multicomponent aqueous solution in neutral as well as in acidic conditions. The kinetic of heavy metals adsorption followed the pseudo-second order model, the calculated values of coefficient of determination for this model were higher than for pseudo-first order and intraparticle diffusion models. The adsorption processes were slow and evenly distributed over time, the maximum adsorption capacities were achieved in $48 \mathrm{~h}$. The experimental data of adsorption tests were correlated well with the Langmuir isotherm model. In addition, nickel ions adsorption processes were well described using Temkin isotherm (with coefficient of determination $\mathrm{R}^{2}$ of 0.976 in acidic conditions and of 0.813 in neutral conditions). Furthermore, the adsorption intensity of heavy metals was affected by initial $\mathrm{pH}$ of the solutions. Maximum adsorption capacities in neutral conditions were higher $(3.010,3.662,4.430,3.800$ and $4.169 \mathrm{mg} \cdot \mathrm{g}^{-1}$ for $\mathrm{Cd}, \mathrm{Cu}, \mathrm{Ni}, \mathrm{Pb}$ and $\mathrm{Zn}$, respectively) than in acidic conditions $(2.684,2.578,3.482,2.592$ and $2.253 \mathrm{mg} \cdot \mathrm{g}^{-1}$, respectively). Therefore, the occurrence of acid rain can affect the dimensions of PRB treatment zone. The conducted studies provide useful information for GAC application as a reactive material in PRBs protecting groundwater along road infrastructure. Parameters calculated on the basis of test results (equilibrium rate constants and adsorption capacities) are the basis for modelling of contaminants flow through the PRB filled with GAC.

\section{REFERENCES}

ALKAN M., DEMIRBAŞ Ö., DOĞAN M. 2007: Adsorption kinetics and thermodynamics of an anionic dye onto Sepiolite. Microporous and Mesoporous Materials 101(3), 388-396.

BARRETT M.E. 2008: Comparison of BMP performance using the international BMP database. Journal of Irrigation and Drainage Engineering 134, 556-561.

BARRETT M., KEARFOTT P., MALINA J. 2006: Stormwater quality benefits of a porous 
friction course and its effect on pollutant removal by roadside shoulders. Water Environment Research, Water Environment Federation 78(11), 2177-2185.

BÉCHET D., DURIN B., LEGRET M., CLOIREC P. 2010: Size fractionation of heavy metals in highway runoff waters. Highway and Urban Environment: Alliance for Global Sustainability Book Series 17(4), 235-244.

BLECKEN G.T., RENTZ R., MALMGREN C., ÖHLANDER B., VIKLANDER M. 2012: Stormwater impact on urban waterways in a cold climate: variations in sediment metal concentrations due to untreated snowmelt discharge. Journal of Soils and Sediments 12, 758-773.

DAVIS A.P., BURNS M. 1999: Evaluation of lead concentration in runoff from painted structures. Water Research 33, 2949-2958.

DAVIS A.P., SHOKOUHIAN M., NI S.B. 2001: Loading estimates of lead, copper, cadmium, and zinc in urban runoff from specific sources. Chemosphere 44, 997-1009.

FACH S., DIERKES C. 2011: On-site infiltration of road runoff using pervious pavements with subjacent infiltration trenches as source control strategy. Water Science and Technology 64(7), 1388-1397.

GAO 13-39 2013 (United States Government Accountability Office) 2013: Water quality.

GOTVAJN A., ZAGORC-KONČAN J. 2009: Bioremediation of highway stormwater runoff. Desalination 248, 794-802.

HALL K.R., EAGLETON L.C., ACIVOS A., VERMEULEN T. 1966: Pore- and solid-diffusion kinetics in fixed-bad adsorption under constant-pattern conditions. Industrial and Engineering Chemistry Fundamentals 5, 212-223.

HO Y. 2006: Second-order kinetic model for the sorption of cadmium onto tree fern: a comparison of linear and non-linear methods. $\mathrm{Wa}$ ter Research 40(1), 119-125.

HO Y.S., MCKAY G. 1999: Pseudo-second order model for sorption processes. Process Biochemistry 34, 451-465.

IBRAHIM H.S., El-KADY A.A., AMMAR N.S., MEESUK L., WATHANAKUL P., ABDEL-WAHHAB M.A. 2013: Application of iso- therm and kinetic models for the removal of lead from aqueous solutions. Journal of Environmental Engineering 139(3), 349-357.

JOSSENS L., PRAUSNITZ J.M., FRITZ W., SCHLÜNDER E.U., MYERS A.L. 1978: Thermodynamics of multi-solute adsorption from dilute aqueous solutions. Chemical Engineering Science 33, 1097-1106.

KAYHANIAN M., SINGH A., SUVERKROPP C., BORROUM S. 2003: Impact of annual average daily traffic on highway runoff pollutant concentrations. Journal of Environmental Engineering-Asce. 129(11), 975-990.

KAYHANIAN M., SUVERKROPP C., RUBY A., TSAY K. 2007: Characterization and prediction of highway runoff constituent event mean concentration. Journal of Environmental Management 85(2), 279-295.

KLUGE B., WESSOLEK G. 2012: Heavy metal pattern and solute concentration in soils along the oldest highway of the world - AVUS autobahn. Environmental Monitoring and Assessment 184, 6469-6481.

LANGMUIR I. 1916: The constitution and fundamental properties of solids and liquids. J. Am. Che. Soc. 38(11), 2221-2295.

LIU H., GAO Q., DAI P., ZHANG J., ZHANG Ch., BAO N. 2013: Preparation and characterization of activated carbon from lotus stalk with guanidine phosphate activation: sorption of Cd(II). Journal of Analytical and Applied Pyrolysis 102, 7-15.

MICHEL M.M., KIEDRYŃSKA L. 2011: Modelling equilibrium data for manganese (II) sorption onto manganese dioxide modifi ed chalcedonite using the non-linear regression method. Ann. Warsaw Univ. of Life Sci. - SGGW, Land Reclam. 43(2), 155-163.

NASIR M.H., NADEEN R., AKHTAR K., HANIF M.A., KHALID A.M. 2007: Efficiency of modified distillation sludge of rose (Rosa centifolia) petals for $\mathrm{Pb}(\mathrm{II})$ and $\mathrm{Zn}$ (II) for aqueous solution. Journal of Hazardous Materials 147(3), 1006-1014.

OTUN J.A., OKE I.A., OLARINOYE N.O., ADIE D.B., OKUOFU C.A. 2006: Adsorption isotherms of $\mathrm{Pb}$ (II), $\mathrm{Ni}(\mathrm{II})$, and $\mathrm{Cd}$ (II) onto PES. Journal of Applied Sciences 6(11), 2368-2376. 
Regulation of the Minister of Environment from 24 July 2006 on conditions to be met when discharging sewage to waters or to the soil and on substances of particular adverse impact on the water environment. Polish Journal of Laws from 2006 No 137, item 984.

REDLICH O., PETERSON D.I. 1959: A useful adsorption isotherm. The Journal of Physical Chemistry 63, 1024-1026.

RIVAS F.J., BELTRAN F.J., GIMENO O., FRADES J., CARVALHO F. 2006: Adsorption of landfill leachates onto activated carbon equilibrium and kinetics. Journal of Hazardous Materials B131, 170-178.

ROEHL K.E., CZURDA K., MEGGYES T., SIMON F., STEWART D.I, 2006: Long-term Performance of Permeable Reactive Barriers, USA. Elsevier, Amsterdam.

SRIVASTAVA V.C., MALL I.D., MISHRA I.M. 2008: Adsorption of toxic metal ions onto activated carbon: study of sorption behaviour through characterization and kinetics. Chemical Engineering and Processing: Process Intensification 47(8), 1269-1280.

SULAYMON A.H., MOHAMMED T.J., Al-NAJAR J. 2012: Equilibrium and kinetics studies of adsorption of heavy metals onto activated carbon. Canadian Journal on Chemical Engineering and Technology 3(4), 86-92.

TEMKIN M.I., PYZHEV V. 1940: Kinetic of ammonia synthesis on promoted iron catalyst. Acta physiochim, URSS 12, 327-356.

VENKATESAN G., SENTHILNATHAN U., RAJAM S. 2013: Cadmium removal from aqueous solutions using hybrid eucalyptus wood based activated carbon: adsorption batch studies. Clean Technologies and Environmental Policy. DOI 10.1007/s10098-0130628-0.

ZAYAT M.E., SMITH E. 2010: Removal of heavy metals by using activated carbon produced from cotton stalks. Canadian Journal of Environmental, Construction and Civil Engineering 1(4), 71-79.
Streszczenie: Usuwanie metali ciężkich na węglu aktywowanym - sorpcja równowagowa $i$ kinetyczna. Węgiel aktywny jest skutecznym sorbentem powszechnie wykorzystywanym do usuwania zanieczyszczeń organicznych i nieorganicznych z roztworów wodnych. W przeprowadzonych doświadczeniach, granulowany węgiel aktywny (GAC) użyto do badania procesów adsorpcji metali ciężkich $(\mathrm{Cd}, \mathrm{Cu}, \mathrm{Ni}, \mathrm{Pb}$ i Zn). Badania (typu batch test) przeprowadzono w funkcji czasu, stężenia metali ciężkich i wartości pH. Otrzymane wyniki wskazują na skuteczne usuwanie wyżej wymienionych metali ciężkich z roztworów wodnych. Podczas badań mechanizmu procesów adsorpcyjnych wykorzystano następujące modele kinetyczne: pseudopierwszego, pseudodrugiego rzędu oraz model wewnątrzcząsteczkowy. Ponadto, wyniki otrzymane z badań sorpcji równowagowej zostały opisane następującymi modelami: Langmuira, Redlicha-Petersona i Temkina. Wykorzystując parametry izotermy Langmuira, obliczono wartości maksymalnych zdolności adsorpcji dla metali ciężkich, które wyniosły dla warunków odczynu obojętnego: $\mathrm{Cd}$ $-3,010, \mathrm{Cu}-3,662, \mathrm{Ni}-4,430, \mathrm{~Pb}-3,800$ i $\mathrm{Zn}$ $-4,169 \mathrm{mg} \cdot \mathrm{g}^{-1}$, i dla warunków odczynu kwaśnego: $\mathrm{Cd}-2,684, \mathrm{Cu}-2,578, \mathrm{Ni}-3,482, \mathrm{~Pb}-2,592$ $\mathrm{i} \mathrm{Zn}-2,253 \mathrm{mg} \cdot \mathrm{g}^{-1}$.

Słowa kluczowe: węgiel aktywny, metale ciężkie, wody spływowe, adsorpcja

\section{MS. received June 2014}

\section{Authors' address:}

Katarzyna Pawluk, Joanna Fronczyk

Zakład Geotechniki, Katedra Geoinżynierii Wydział Inżynierii i Kształtowania Środowiska SGGW

ul. Nowoursynowska 159, 02-776 Warszawa

Poland 